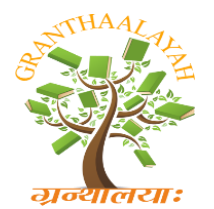

INTERNATIONAL JOURNAL OF RESEARCH GRANTHAALAYAH

A knowledge Repository

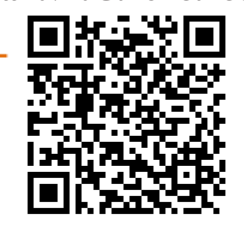

Management

\title{
IMPACT OF FOREIGN DIRECT INVESTMENT ON HIGHER EDUCATION
}

\author{
Kalpana Singh $^{* 1}$, Dr. Alka Awasthi ${ }^{2}$ \\ ${ }^{* 1}$ Research Scholar, Barkatullah University Bhopal, INDIA \\ ${ }^{2}$ Research Guide, HOD MBA, TIT Bhopal (MP), INDIA
}

\begin{abstract}
The purpose of this paper is to examine how Foreign Direct investment (FDI) can be leveraged to enhance its impact on Higher Education.

This paper attempts to discuss the possibilities of bringing quality, excellence and more opportunities in "Higher education" through the FDI route.

FOREIGN DIRECT INVESTMENT: Education sector is growing day by day and gaining lots of importance in the world and India as well. Education Industry is likely to grow by the Gross Enrolment Ratio (GER) by 2020. Foreign Direct Investment up to 100\% is allowed in most of the sectors more significantly, Thus the role of private sector in higher education has significantly increased in the last decade \& the growth of the this sector alone, estimates, to grow to US\$ 70 billion by 2013 and US\$ 115 billion by 2018. The study focuses on advantages of FDI in Education with reference to India particularly, and evaluates the advantages and disadvantages of going in for FDI.

Foreign Direct Investment has always been a matter of concern for India, when it comes to education sector 100\% FDI is allowed by the Government but, besides its advantages, it has some limitations or disadvantages also. In this paper an attempt has been made by the authors to highlight the good and bad effects of FDI in Education Sector
\end{abstract}

Keywords:

Foreign Direct Investment, Higher Education, Public sector, Private sector.

Cite This Article: Kalpana Singh, and Dr. Alka Awasthi, "IMPACT OF FOREIGN DIRECT INVESTMENT ON HIGHER EDUCATION" International Journal of Research Granthaalayah, Vol. 4, No. 5 (2016): 80-91.

\section{INTRODUCTION}

Foreign direct investment (FDI) is an investment in a business by an investor from another country for which the foreign investor has control over the company purchased.

Businesses that make foreign direct investments are often called multinational corporations (MNCs) or multinational enterprises (MNEs). 
Foreign Direct Investment has always been a matter of concern for India, when it comes to education sector $100 \%$ FDI is allowed by the Government but, besides its advantages, it has some limitations or disadvantages also. In this paper an attempt has been made by the authors to highlight the good and bad effects of FDI in Education Sector.

In India, education is the key to nation-building. It is also a well-accepted fact that providing the right knowledge and skills to the youth can ensure the overall national progress and economic growth. The Indian education system recognizes the role of education in instilling the values of secularism, egalitarianism, respect for democratic traditions and civil liberties and quest for justice. The education sector in India is evolving and has emerged as a strong potential market for investments in training and education sector, due to its favorable demographics (young population) and being a services-driven economy. Further, India's expanding role in sectors such as software development, generic pharmaceuticals and healthcare, would require the country to invest into learning and training segment as well. The education sector in India is also considered as one of the major areas for investments as the entire education system is going through a process of overhaul.

Education is gaining lot of importance in India. Education Industry is likely to grow by the size of the public education sector is $\$ 40$ billion and the private sector amounted to $\$ 60$ billion in 2011-2012. Foreign Direct Investment up to $100 \%$ is allowed in most of the sectors more significantly, there is an expectation that FDI would reach US\$ 1000 million this year. The study focuses on advantages of FDI in Education with reference to India particularly, and evaluates the advantages and disadvantages of going in for FDI.

Foreign direct investment is a passive investment in the securities of another country such as stocks and bonds and also known as portfolio investment. FDI explains about the net inflows of investment to acquire a management interest and also management control and profit sharing as a part of the national accounts of a country. It usually refers to a measure of foreign ownership of productive assets, such as factories, mines and land. Increasing foreign direct investment can be used as one measure of growing economic globalization. India is the second most FDI destination as per the survey by UNCTAD after China for transnational corporations during 2010-2012.As pet the data, the second sectors which are attracted higher inflows were services, telecommunication, Construction, Media and computer Hardware and Software. The foreign direct investment involves the transfer of technology and expertise, and participation in the joint venture and management.

Foreign direct investment provides highly productive advantages both governmental and private companies and organizations of all over the world. Foreign direct investment is profitable both to the country receiving investment (foreign capital and funds) and the investors. India has one of the world's largest education systems, which includes 1.3 million schools, 30,000 colleges and 542 universities. In last year's budget (2011-2012), Finance Minister Pranab Mukherjee allocated Rs 52,057 crore for the sector. The size of the public education sector is $\$ 40$ billion and the private sector amounted to $\$ 60$ billion in 2011. Current law allows 100 per cent FDI in education. According to the Confederation of Indian Industry (CII), another simple and best way to attract private investment in higher education is possible through foreign direct investment 
(FDI), and for those certain amendments to be made in the Foreign Currency Regulation Act (FCRA).

Foreign investment considered in several types such as Portfolio investment, foreign loans and foreign direct investment are the three important classifications. Out of these foreign direct investments in industry and services are the most useful. According to the International Monetary Fund, "direct investment reflects the aim of obtaining a lasting interest by a resident entity of one economy (direct investor) in an enterprise that is resident in another economy (the direct investment enterprise). The "lasting interest" implies the existence of a long-term relationship between the direct investor and the direct investment enterprise and a significant degree of influence on the management of the latter". Foreign Direct Investment means designing and implementing macroeconomic stability policies. It can be safely said that the Education has a very important role in shaping the Indian economy. The sector has a total output and the size of the public education sector is $\$ 40$ billion and the private sector amounted to $\$ 60$ billion and allocated Rs 52,057 crore for the sector in 2011-2012.

FDI is a predominant and vital factor in influencing the contemporary process of global economic development. The study attempts to analyze the important dimensions of FDI in India. The study works out the trends and patterns, main determinants and investment flows to India. The study also examines the role of FDI on economic growth in India. FDI is considered as the most suitable form of external finance. And it is increase in competition for FDI inflows particularly among the developing nations.

\section{OBJECTIVES}

- To scrutinize the need of FDI in education in India.

- To analyze the current trends and patterns of flow of FDI towards education sector

- To analyze the status of Indian higher education system and need of FDI in education sector in India

- To examine the opportunities \& challenges of FDI in education sector in India.

- To study the implications of bringing in FDI in Indian education.

- To trace out the barriers for FDI in Indian education.

- To suggest the removal of various barriers for FDI in Indian education system.

\section{FOUR MORE BILLS TABLED OBJECTIVES}

1) To study the current trends and patterns of flow of FDI towards education sector.

2) To assess FDI as a determinant for growth of Education Sector

3) To evaluate the impact of establishment of foreign universities in India.

4) To study the status of Indian higher education system and need of FDI in education sector in India.

5) To study the opportunities of FDI in education sector in India

6) To study the challenges of FDI in education sector in India

7) To analyze the importance of regulatory bodies in inviting the foreign universities.

8) To study the implications of bringing in FDI in Indian education.

9) To study the aspects of FDI entry at different levels in Indian education system. 
10) To trace out the barriers for FDI in Indian education.

11) To suggest the removal of various barriers for FDI in Indian education system

12) To study the need of FDI in education in India.

Table 1: ES2 Effects of globalisation processes on education

\begin{tabular}{|c|c|c|c|c|}
\hline & \multicolumn{4}{|c|}{ The effects of : } \\
\hline & Schooling & Vocational education & Tertiary education & Foreign education \\
\hline $\begin{array}{l}\text { Trade } \\
\text { (exports) }\end{array}$ & $\begin{array}{l}\text { A year of primary } \\
\text { schooling raises wages } \\
\text { by more than a year of } \\
\text { secondary schooling } \\
\text { (estimated Mincerian } \\
\text { equations) } \\
\text { Schooling leads to } \\
\text { higher growth and } \\
\text { productivity and thus } \\
\text { exports, but macro effect } \\
\text { depends on type of } \\
\text { country (education } \\
\text { important for catch-up in } \\
\text { low income countries) } \\
\text { Good quality schooling } \\
\text { is basis for further } \\
\text { education and training, } \\
\text { including for } \\
\text { entrepreneurship }\end{array}$ & $\begin{array}{l}\text { To upgrade to higher } \\
\text { value added exports } \\
\text { and remain } \\
\text { competitive (in case } \\
\text { studies, e.g. in } \\
\text { Thailand) } \\
\text { Entrepreneurship } \\
\text { skills relevant for } \\
\text { marketing of } \\
\text { products and services } \\
\text { (e.g. for marketing } \\
\text { forest products from } \\
\text { Bolivia/Mexico) } \\
\text { Communication and } \\
\text { leadership skills for } \\
\text { participating in } \\
\text { global value chains }\end{array}$ & $\begin{array}{l}\text { Education affects the } \\
\text { structure of exports: } \\
\text { the more years the } \\
\text { more sophisticated } \\
\text { and diversified the } \\
\text { exports (e.g. } \\
\text { graduates behind } \\
\text { Chilean forestry } \\
\text { exports) } \\
\text { Important for } \\
\text { participating in } \\
\text { knowledge intensive } \\
\text { services exports (e.g. } \\
\text { India, Singapore) }\end{array}$ & $\begin{array}{l}\text { Foreign education } \\
\text { and networks of } \\
\text { national abroad are } \\
\text { associated with } \\
\text { further trade in } \\
\text { goods and services } \\
\text { (see next matrix) }\end{array}$ \\
\hline $\begin{array}{l}\text { Private cross- } \\
\text { border financial } \\
\text { flows (inward } \\
\text { FDI) }\end{array}$ & $\begin{array}{l}\text { Schooling is an } \\
\text { important explanatory } \\
\text { variable in regressions } \\
\text { explaining inward FDI } \\
\text { in developing countries }\end{array}$ & $\begin{array}{l}\text { Technical and } \\
\text { engineering skills for } \\
\text { manufacturing FDI } \\
\text { (Asian examples). } \\
\text { Little effect in simple } \\
\text { assembly operations }\end{array}$ & $\begin{array}{l}\text { Availability of } \\
\text { technical and } \\
\text { engineering } \\
\text { graduates facilitates } \\
\text { manufacturing FDI } \\
\text { (case studies in } \\
\text { Singapore, Malaysia, } \\
\text { Costa Rica) }\end{array}$ & $\begin{array}{l}\text { Expatriates / } \\
\text { courses in natural } \\
\text { resources industry. } \\
\text { Might lead to } \\
\text { diaspora investment } \\
\text { (e.g. India) }\end{array}$ \\
\hline $\begin{array}{l}\text { Migration } \\
\text { (emigration) }\end{array}$ & $\begin{array}{l}\text { Data on skill intensity of } \\
\text { migrations show there is } \\
\text { little effect from primary } \\
\text { education and a } \\
\text { moderate effect from } \\
\text { secondary }\end{array}$ & $\begin{array}{l}\text { Trained nurses, } \\
\text { teachers, accountants } \\
\text { and IT specialists in } \\
\text { demand in developed } \\
\text { countries (see UK } \\
\text { data on work permits) }\end{array}$ & $\begin{array}{l}\text { Strong effect on } \\
\text { emigration, but in } \\
\text { particular } \\
\text { occupations/ } \\
\text { countries (e.g. } \\
\text { Zambian doctors) }\end{array}$ & $\begin{array}{l}\text { Students stay } \\
\text { abroad for work; } \\
\text { skilled foreigners } \\
\text { associated with } \\
\text { multinational } \\
\text { enterprises }\end{array}$ \\
\hline
\end{tabular}

\section{ANALYSIS}

1) Government has taken a step further for the free entry to A-grade global universities into India without any restriction

2) Central Government has on 15 March 2010 unanimously approved the Foreign Educational Institutions Regulation of Entry and Operations, (Maintenance of Quality and Prevention of Commercialization) Bill 2010 (the "Bill").

3) New bill will allow foreign providers to set up Independent colleges

4) It is not clear whether the foreign universities would take care of the needs of the underprivileged sections. 


\section{FACTORS ATTRACTING FOREIGN DIRECT INVESTMENT IN INDIA}

Various factors that are attracting foreign direct investment in India include large and growing middle class population in the country, majority of the workers are educated and can speak good English, and the wages are also low. A potentially huge market capable of yielding much higher returns than in other countries has been a major attraction for foreign investors. All these factors have helped to increase the Potential of the Indian Market for Foreign Investment.

Sectors of the Indian market having potential for foreign direct investment are:

- Services

- Telecommunications

- Drugs and pharmaceuticals

- Transportation industry

- Cement and gypsum products

- Electrical equipment's

- Education Increasing the Potential of the Indian Market for Foreign Investment: Initiatives that can further increase the potential of the Indian market for foreign investments are

- Further developments in infrastructure.

- Simplification of FDI process.

- Reform measures.

\section{FOREIGN DIRECT INVESTMENT IN EDUCATION SECTOR}

Foreign Educational Institutions Regulation of Entry and Operations, (Maintenance of Quality and Prevention of Commercialization) Bill 2010 Central Government has on 15 March 2010 unanimously approved the Foreign Educational Institutions Regulation of Entry and Operations, (Maintenance of Quality and Prevention of Commercialization) Bill 2010 (the "Bill"). The Bill proposes to allow foreign education providers to set up campuses in India and offer degrees and diplomas to students. The Union human resource ministry announced that 100 per cent foreign direct investment would be allowed under the law proposed for higher education, even as the Group of Ministers on the issue had that FDI of only up to 50 per cent could be permitted in the sector. The proposed Bill has many clauses to check its potential misuse. It prescribes a timebound format to grant approval to foreign educational institutions to set up campuses in India. They would be registered with the University Grants Commission (UGC) or any other regulatory body (which supercedes UGC), which will scrutinize proposals of aspiring institutions according to India's priorities. Foreign universities aspiring to set up a campus will also have to deposit Rs. 50 crore as corpus fund and cannot take back the surplus generated from education activities here. Moreover, a foreign education provider shall, out of the income received from the corpus fund, utilise not more than 75 per cent of it for the development of its institutions in India. The human resource development minister had made it clear in the past that quotas would be implemented if the government allows foreign universities into India. Infact applying the new reservation policy in foreign educational institutions when they come to India has been one of many issues that Man Mohan Singh had taken up against the proposal to allow FDI in education which was vigorously pushed by the commerce ministry.

Already a number of Universities and foreign companies that operate in the education sector have shown keen interest to enter India. The outflow from India on education to foreign 
countries is more than Rs 20,000 crore. The commerce ministry has been arguing for liberalizing higher education sector in India for foreign investment. The remaining income will be deposited in the corpus fund. The Bill states that a foreign institution "shall not impart education in India unless it is recognised and notified by the central government as a foreign education provider under the proposed legislation" and offers education in conformity with the standards laid down by the statutory authority, and of comparable quality.

According to the Confederation of Indian Industry (CII), another simple way to attract private investment in higher education, especially foreign direct investment (FDI), would be to make certain amendments in the Foreign Currency Regulation Act (FCRA). Current law allows 100 per cent FDI in education. For-profit entities are not allowed to get licences from the University Grants Commission and the All India Council for Technical Education (AICTE) or function as private universities under Acts of different state governments. Hence, the investment vehicle is often a Society or a Trust or a Section 25 company. This is one of the major sectors, which is enormously benefited from foreign direct investment. A remarkable inflow of FDI in various industrial units in India has boosted the economic life of country. Employees of the country which is open to FDI get acquaint with globally valued skills in this sector. FDI has also ensured a number of employment opportunities by aiding the setting up of educational institutions in various corners of India.

\section{FACTORS FAVOURING PROMOTION OF FDI}

Increased Investment in higher education will lead to:

- Increased Institutions $\neg$

- Enhanced Access to the best universities of the world. $\neg$

- Opportunities of International Qualification. $\neg$

- World class labs and libraries. $\neg$

- Competition leading to quality improvements. $\neg$

- Curriculum and Technological innovation. $\neg$

- Research $\neg \&$ development.

\section{SWOT ANALYSIS IN EDUCATION SECTOR INDUSTRY IN INDIA}

Strength - The education sector industry is a strong and well developed industry which is currently growing at high rate; this aspect gives the industry a lot of strength. With the increase in the level of education sector has a well-educated and skilled workforce with innovative ideas and technology which is an added positive aspect of the industry. The competitiveness of the education industry has enabled the industry to grow technically both vertically and horizontally, which is another positive aspect in the industry. India also offers strategic location and market in terms of its high population which is a boost to the industry.

Weakness - Among the weakness in the industry, a current weakness may be inability to adhere to ethical standards in the industry which has lead to lawsuits filed against some media industries. The industry also has been slow in its growth only picking up in the recent past, thus its innovation and marketing strategies may be not competitive on the global arena. In some cases education sector is commercialized. 
Opportunities - According to the industry experts the industry still has room to expand within India as this sector is wide and has good opportunity in future. Educational services are being provided with many organizations and thus this offers the industry to increase its market share. The high technological innovation such as innovative techniques in teaching are used includes projectors, LCD's, online training and so on. Which is happening everyday also presents a good opportunity for the education industry to utilize the latest technology in expanding its product mix or improving existing ones hence reaching or increasing its market? There is exists new business in the globally for this industry.

Threats - Though India can be said to be stable political, the country his known for frequent changes in government administration and instability in some regions or states, this issue negatively affects the education and it is threat to the education sector. Also government legislations in India are known to some extend as hindering the growth of industry especially for Universities. Some of the threats are commercialization of this sector.

\section{OPPORTUNITIES FOR INVESTMENT IN EDUCATION SECTOR}

1) The Market Size is huge hence, we have high demand

2) Our Mindset of quality means foreign degree without much distinction

3) Our Vast Reservoir of Intellectual Resource

4) Our Regulatory Mechanism is deterrent for high quality, promoting for inferior quality 5. India has a potential of about 50,000 foreign students in next couple of years, whereas presently only 10,000 are studying in India.

\section{CHALLENGES FACED BY THE EDUCATION SECTOR IN INDIA}

1) Accessibility:

2) Drop-out rate: nearly 40 per cent drop out at the primary stage.

3) Social Barriers:.

4) Relevance: more skill-oriented - both in terms of life-skills as well as livelihood skills

5) Management: needs to build in greater decentralization, accountability, and professionalism, Resources:

6) Pre-condition: "Not-for-profit" basis

7) Regulation

8) Alliances

9) Approval procedures cumbersome and tedious

10) Quality and relevance of education: Infrastructure, curriculum, industry involvement and Employability of graduates due to lack of effective training.

11) Financing higher education institutions :

12) Technology - Low technology penetration

\section{ADVANTAGES OF FDI}

In the context of foreign direct investment, advantages and disadvantages are often a matter of perspective. An FDI may provide some great advantages for the MNE but not for the foreign country where the investment is made. On the other hand, sometimes the deal can work out 
better for the foreign country depending upon how the investment pans out. Ideally, there should be numerous advantages for both the MNE and the foreign country, which is often a developing country. We'll examine the advantages and disadvantages from both perspectives, starting with the advantages for multinational enterprises (MNES).

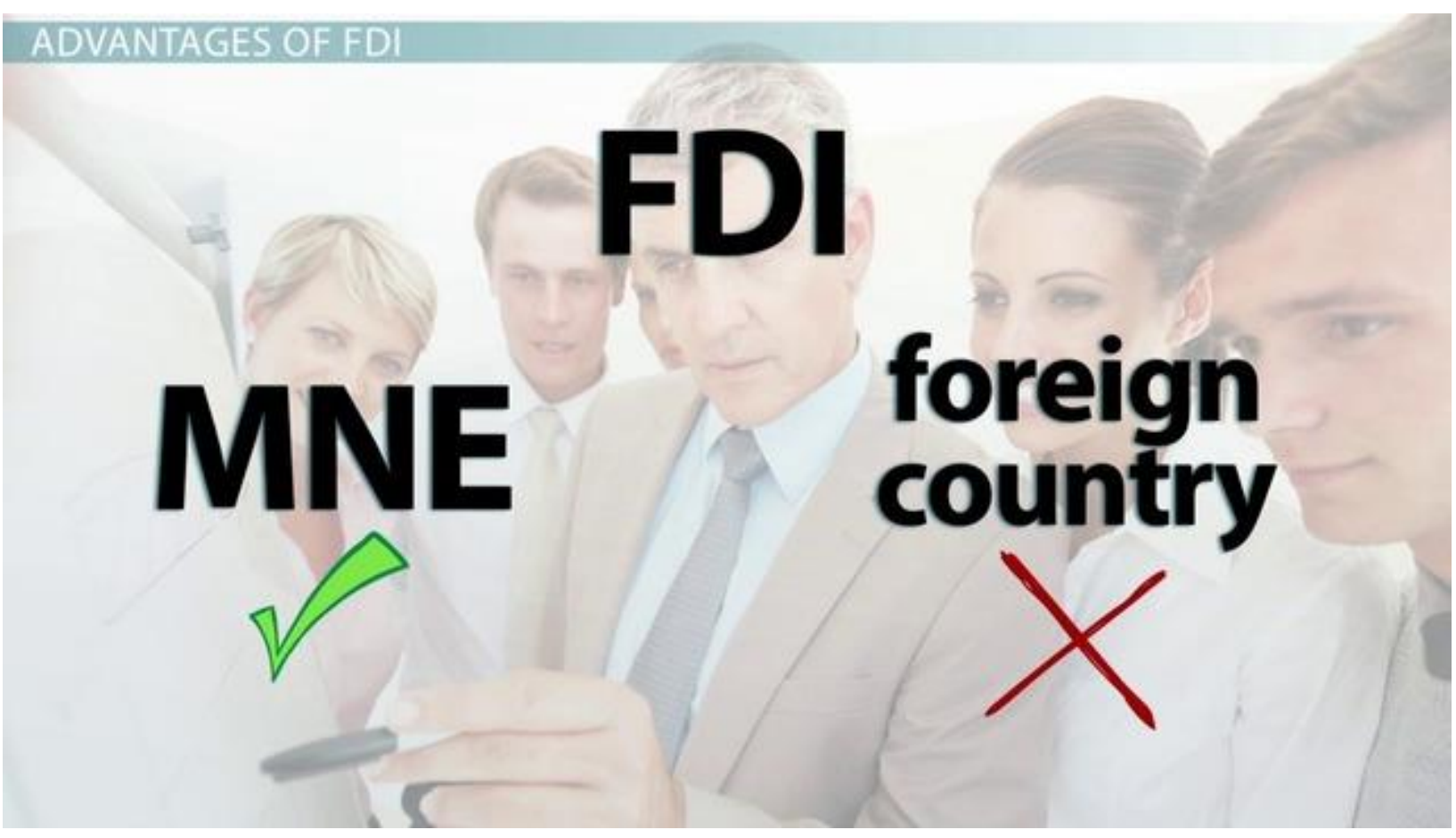

Access to markets: FDI can be an effective way for you to enter into a foreign market. Some countries may extremely limit foreign company access to their domestic markets. Acquiring or starting a business in the market is a means for you to gain access.

Access to resources: FDI is also an effective way for you to acquire important natural resources, such as precious metals and fossil fuels. Oil companies, for example, often make tremendous FDIs to develop oil fields.

Reduces cost of production: FDI is a means for you to reduce your cost of production if the labor market is cheaper and the regulations are less restrictive in the target foreign market. For example, it's a well-known fact that the shoe and clothing industries have been able to drastically reduce their costs of production by moving operations to developing countries.

FDI also offers some advantages for foreign countries. For starters, FDI offers a source of external capital and increased revenue. It can be a tremendous source of external capital for a developing country, which can lead to economic development.

For example, if a large factory is constructed in a small developing country, the country will typically have to utilize at least some local labor, equipment, and materials to construct it. This will result in new jobs and foreign money being pumped into the economy. Once the factory is constructed, the factory will have to hire local employees and will probably utilize at least some 
local materials and services. This will create further jobs and maybe even some new businesses. These new jobs mean that locals have more money to spend, thereby creating even more jobs.

Additionally, tax revenue is generated from the products and activities of the factory, taxes imposed on factory employee income and purchases, and taxes on the income and purchases now possible because of the added economic activity created by the factory. Developing governments can use this capital infusion and revenue from economic growth to create and improve its physical and economic infrastructure such as building roads, communication systems, educational institutions, and subsidizing the creation of new domestic industries.

Another advantage is the development of new industries. Remember that a MNE doesn't necessary own all of the foreign entity. Sometimes a local firm can develop a strategic alliance with a foreign investor to help develop a new industry in the developing country. The developing country gets to establish a new industry and market, and the MNE gets access to a new market through its partnership with the local firm.

Finally, learning is an indirect advantage for foreign countries. FDI exposes national and local governments, local businesses, and citizens to new business practices, management techniques, economic concepts, and technology that will help them develop local businesses and industries.

\section{DISADVANTAGES TO MNES}

Of course, there can also be some drawbacks for foreign direct investment. We'll start with the disadvantages for multinational enterprises (MNEs).

Higher education is a typical word to define; its meaning is different in different areas. In India a higher education qualification at degree level takes a minimum of three years to complete, more typically four. It will have a theoretical underpinning, it will be at a level which would qualify someone to work in a professional field and it will usually be taught in an environment which also includes advanced research activity. Shortly, Higher education mainly and generally means university level education. It offers a number of qualifications ranging from Higher National Diplomas and Foundation Degrees to Honors Degrees and as further step, Postgraduate programmes such as Masters Degrees and Doctorates. These are recognized throughout the world as representing specialist expertise supported by a wide range of skills that employers find very useful. Further education is generally includes those post graduate studies in where you can gain your Master and Doctorate degree Higher Education in India-Current status:

Higher Education in India has evolved in distinct and divergent streams with each stream monitored by an apex body, indirectly controlled by the Ministry of Human Resource Development. The 433 universities/ institutions are mostly funded by the state governments. However, there are 44 important universities called Central universities, which are maintained by the Union Government and because of relatively large funding, they have an edge over the International Journal of Social Science \& Interdisciplinary.

Education sector assumes greater significance in developing countries like India. This sector offers huge untapped market. The higher education sector, owing to its huge potential, holds very 
promising prospects. Increase in number of Educational Institutions in India has been remarkably rapid. India faces a big challenge to provide education to young people, especially in far-flung locations. The present paper makes an attempt to study the current scenario of FDI in education sector highlighting the positive and negative impacts of it on the society and economy as a whole. The research approach is exploratory in nature. This paper has major implications for educationists who intend to reap the benefits of FDI as well as Government who need to frame suitable policies.

The education sector in India is divided into two sub segments; the key segment comprises of schools and higher education, while the other segment comprises of coaching classes, preschools and vocational trainings. The Government of India has recently ignited reforms by opening up certain sectors to foreign investment, which would ideally result in increased economic growth and employment generation. Government of India has permitted foreign direct Investment (FDI) up to 100 per cent through the automatic route.

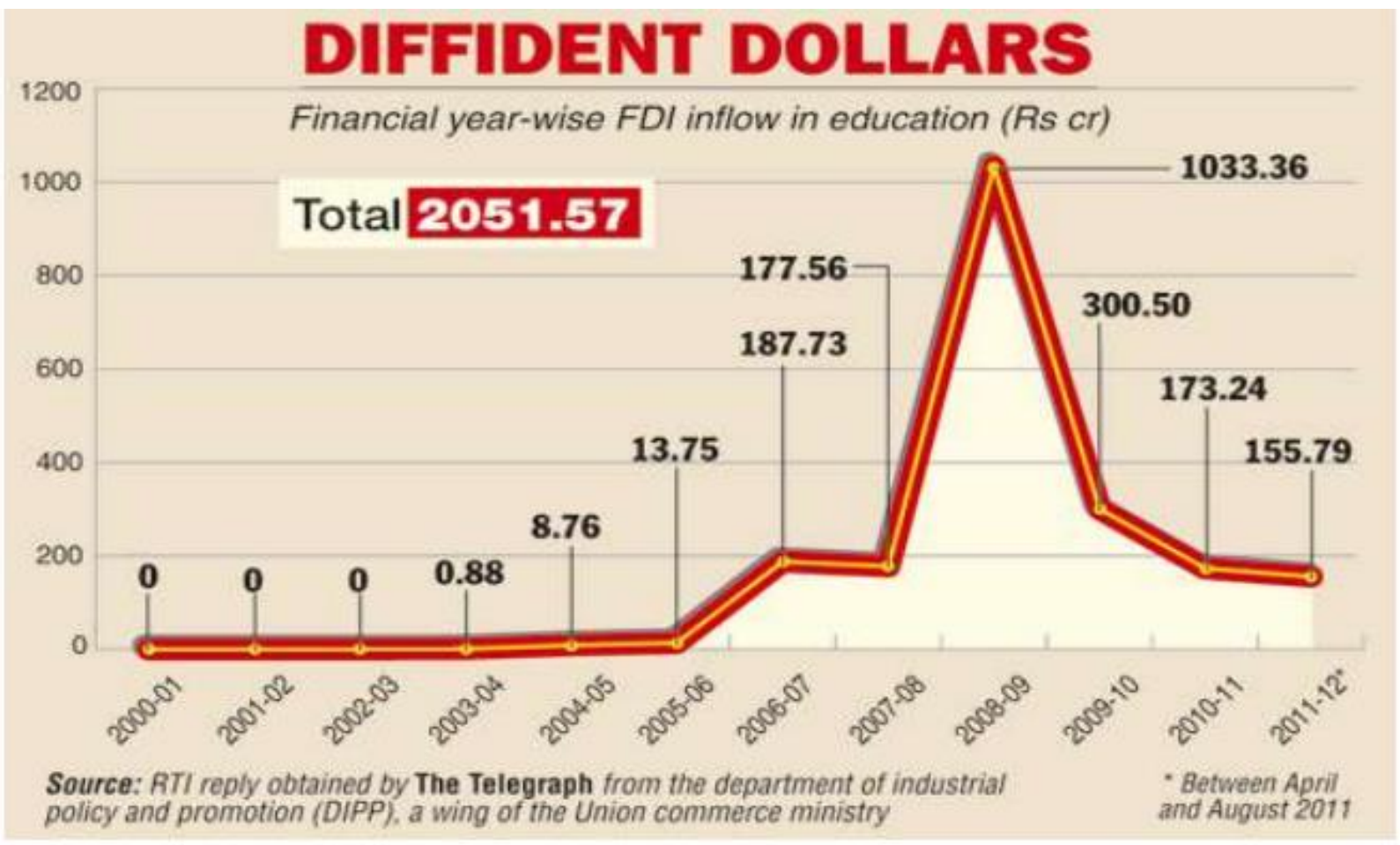

India's education sector has witnessed significant expansion since the government approved FDI in April 2000, thus providing a huge opportunity for investment. Yet FDI remained zero in the first three years, increased till 2008-09 and then kept falling again. In the past 11 years, the total FDI in education has stood at Rs 2,051 crore, the yearly average of Rs 186 crore being one-tenth of one per cent of what the Centre and state governments annually spends in this sector. Government has proposed 100 percent foreign direct investment in higher education and hinted at making reservation mandatory in the institutions to be set up by foreign universities in the country. Once approved by the Cabinet and passed as law, the Foreign Education Providers (Regulation) Bill will grant deemed university status to such institutions.Recently Shri Arjun Singh, Minister HRD said, "I do not think that there are any ideological problems about FDI. But some kind of control has to be maintained. Education is a sensitive area". Before finalizing any 
policy on FDI in higher education, there are various issues that need to be discussed. There is now no law in the country to regulate the entry and operations of foreign education providers. That is why FDI inflow is not happening for setting up institutions or offering courses," he said. "The proposed law provides for a proper mechanism for investment in this sector." Sudarshan was less confident, citing how the bill retains the not-for-profit mantra. This newspaper has reported how the bill requires foreign universities to compulsorily deposit between Rs 25 crore and Rs 100 crore as a sort of security, and prods them to open campuses in backward regions. Under current rules, 100 per cent FDI is allowed in education through the "automatic route". This means a foreign company can directly invest in an Indian firm without prior approval from the government or the RBI. However, within 30 days of the receipt of the FDI, the Indian company is required to report to the RBI's regional office.

\section{CONCLUSION}

At last it is not wrong to state that India badly need funds for the development of education sector as it is beyond the capability of country to cater the need of finance. In order to tackle this situation $100 \%$ FDI has been allowed by the Govt. but besides its advantages and it is having certain severe disadvantages which needs strict action on the part of Indian govt. A regulatory body should be framed otherwise India might face some bad consequences in context of culture and autonomy of foreign education providers.

\section{REFERENCES}

[1] Anandakrishnan, M., 2006, "FDT and False Hopes", Frontline, Vol NO.:23.

[2] Arun Nigvekar (2001), "Gats And Higher Education", University Grants Commission. SRJIS/BIMONTHLY/ Shilpa Kaura (408-415)

[3] SEPT-OCT, 2013. VOL. II/VIII www.srjis.com Page 414

[4] Ambani, M. and K. Birla (2001): Report on a Policy Framework for Reforms in Education, Government of India, New Delhi.

[5] Chinnammai, "Effects of .Globalization On Education And Culture", ICDE International Conference, 2005.

[6] J.L. Azad (1971), Report of The Study Of The Patterns, Procedures And Policies Of Financing Of Higher Education In India, Planning Commission.

[7] K.D. Raju, Barriers To Trade in Education Services Under The Gats Experience", Amity Law Review, Vol. 5, Part 1, January 2004-June 2004.

[8] McBurnie, G., (2004): Transnational Education: National and International Responses, in K. B. Powar and K. L. Johar (Editors), Private Initiatives in Higher Education, pp. 78-93, Yamunanagar: Sneh Prakashan.

[9] Nigavekar, A. S., (2001): GATS and Higher Education: What is at stake for India, Paper circulated at a National -level Meeting on 'Trade in Education Service under WTO Regime", NIEPA, New Delhi.

[10] Pawan A., "Higher Education Policy Many Contradictions", Economic And Political Weekly, 2006, November 11, 2006

[11] Powar, K. B., (2002): WTO, GATS and Higher Education: An Indian Perspective, AID Occasional Paper 2002/1, AID, New Delhi.

[12] Rani, Geetha. P. (2002): "Financing Higher Education in India during the Post 
Reform Period: Focus on Access and Equity", NIEP A Occa5ional Paper, No. 31, NIEP, New Delhi, September, 2002.

[13] Satish Y. Deodhar(2002), "Managing Trade In Educational Services: Issues for India's Response In WTO Negotiations," lima Working Paper No. 2001-10-03.

[14] http://www.researchandmarkets.com/research/f4dd10/industry_insight

[15] Business world Issue Dated 02-04-2012

[16] www.ventureintelligence.in

[17] www.ficci-hen.com/mrbhushan

[18] www.pwc.com/in/en/industries/education.jhtml

[19] http://www.ebc-india.com/practicallawyer

[20] IDFC SSKI India research report June 2009

[21] KPMG Edge forum report 2012

[22] UIS statistics in brief General Profile -India 